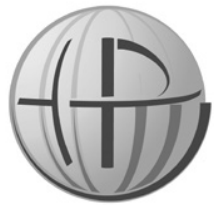

Tomasz Litwin

http://orcid.org/0000-0001-6956-6959 Jesuit University Ignatianum in Krakow tomasz.litwin@gmail.com

DOI: $10.35765 / H P .1841$

Horyzonty Polityki 2021, Vol. 12, No 39

\title{
The Reflection on the Human Nature and the Power in the Constitution of the Republic of Poland of 1997 from the Legal-Constitutional Research Perspective
}

\begin{abstract}
RESEARCH OBJECTIVE: The main research aim of the article is the analysis of the relations between the conception of the human nature and the main purposes of the power in the rules of the Constitution of Poland.

THE RESEARCH PROBLEM AND METHODS: The research problem of the article is how the constitutional conception of the human nature influences the conception of power and its purposes expressed in the Constitution. The article presents the legal-constitutional research perspective and is based on various methods of interpretation of the constitutional rules.
\end{abstract}

THE PROCESS OF ARGUMENTATION: The article analyses the constitutional conceptions of the human nature, power and its purposes, as well as their mutual relations.

RESEARCH RESULTS: It seems that the constitutional conception of the human nature has only partial influence on the rules of the constitution describing the power and its purposes.

CONCLUSIONS, INNOVATIONS AND RECOMMENDATIONS: The conception expressed in the preamble of the Constitution describing the Polish citizens as accepting such fundamental and universal values as truth, justice, good and beauty is inadequate. It should be removed and these values

Sugerowane cytowanie: Litwin, T. (2021). The Reflection on the Human Nature and the Power in the Constitution of the Republic of Poland of 1997 from the Legal-Constitutional Research Perspective Horyzonty Polityki, 12(39), 67-88. DOI: 10.35765/HP.1841. 
could be introduced to art. 8 along with such value as "wisdom", as the set of fundamental values protected by the Constitution.

\section{KeYwORDS:}

power, authority, human nature, constitution, values

\section{INTRODUCTORY REMARKS}

The main research aim of the article is to analyse the relations between the human nature and the power in the rules of the Constitution of Poland of 1997. The constitutional construction of the rules concerning the organisation of power is very often influenced by the general conviction about the human nature - should people be regarded as good or bad. Moreover, such construction should also respond to the general assumption that the power generally corrupts people who hold it. These convictions inspired Founding Fathers to introduce to the Constitution of the USA legal mechanisms of the separation of power and checks and balances (Małajny, 1985, pp. 165-174). Therefore, I would like to analyse if the Constitution of Republic of Poland of 1997 presents some vision of the human nature and if so what such vision is. I also would like to check the potential influence of such vision on the constitutional construction of the rules concerning the organisation of power. This aim is associated with the following questions: how the rules of the Constitution describe human nature and power?; what are the relations between the human nature and the power with its purposes that justify it?

The human nature seems to be broadly described in the preamble of the Constitution stating that the Polish citizens are equal and truth, justice, good and beauty are the universal values. According to art. 3031 , every person possesses the dignity and is free. According to art. 4, the supreme power shall be vested in the Nation that shall exercise it through its representatives or directly. The public power is limited, as the state power it is divided and balanced (art. 10) and the whole public power is decentralised (art. 15 para. 1). The general purposes of the Republic of Poland are proclaimed in art. 5: safeguarding the independence and integrity of territory of Poland, ensuring the human freedoms and rights, security of the citizens, safeguarding the 
national heritage and ensuring the protection of the natural environment pursuant to the principles of sustainable development. If such are purposes of the existence for Republic of Poland, it seems that an assumption could be made that these general purposes are the reason for existence of the organs of public power (authority) and the power on its own in Poland.

It seems that the text of Constitution suggests rather positive vision of the human nature. The Constitution seems to regard humans as worthful beings stating that they pose dignity, freedom (liberty) and are equal. Moreover, Constitution declares such values as truth, justice, good and beauty as universal, which would mean that they should somehow influence our way of life. This suggests that the adequate constitutional conception of power would not provide limitations and would include mechanisms of a broad participation in performing the power. However, the constitutional conception of power does not seem to be influenced by this vision of the human nature. The purposes of power from art. 5 of the Constitution are only partially justified by the conception of the human nature presented in the Constitution. The organisation of power in Poland is based on the principle of division of power and sovereignty of Nation, and the latter one has little influence on the ordinary exercising of power. Therefore, it seems that the constitutional vision of human nature does not correspond to the rules of the Constitution concerning the organisation of power.

This article is written from the constitutional-legal research perspective based on the interpretation of the rules of the Constitution. Language-logical, teleological, systematic, judicial and doctrinal (legal literature) methods of the interpretation of the legal rules were used. It should be emphasised that this article will not contain general considerations on what "power", "truth", "justice", "good", or "beauty" is, I only want to focus on how we understand such terms according to the Constitution. 


\section{THE CONCEPTION OF THE HUMAN NATURE IN THE POLISH CONSTITUTION}

The term "human nature" means a group of characteristics that constitutes and determines human identity ${ }^{1}$. The preamble of the Constitution, which is an integral and normative fragment of the legal text (Tuleja, 2019, pp. 23-24; Garlicki, Derlatka, 2016, pp. 36-40), states that:

we, the Polish Nation - all citizens of the Republic, both those who believe in God as the source of truth, justice, good and beauty, as well as those not sharing such faith but arising those universal values from other sources, equal in rights and obligations towards the common good - Poland ${ }^{2}$.

This fragment of the preamble lists four fundamental values: truth, justice, good and beauty and calls them "universal". These values are also described further in the preamble as "universal human values" (Piechowiak, 2020, Legalis). Moreover, the fragment above somehow links these values with "all citizens of Republic" (of Poland). This link leads to the question what, in the light of text of the Constitution, is the relation between the Polish citizens and these values. There could be different answers. One answer is that these values have only importance to help interpreting the rules of the Constitution. Another answer is that these values should be considered in the process of interpretation of the Constitution but they are also recognised as values in the Polish society. The next answer is that these values are not only recognised as such but also similarly understood. The last possible answer is that these values are not only recognised as such and similarly understood, but are also determining the way of life of the Polish citizens. I would cautiously support the view that the described universal constitutional values can be useful in the interpretation of the Constitution but also that the Constitution expresses a vision of the Polish society, where the truth, justice, good

1 Descriptions of the terms: "human nature", "truth", "justice", "good" and "beauty" in further text are based on the definitions published in: https:// encyklopedia.pwn.pl/ and https://sjp.pwn.pl/ (access: 09.01.2020).

2 http://www.sejm.gov.pl/prawo/konst/angielski/kon1.html (access: 25.12. 2019). 
and beauty are recognised values and there is common general understanding of them. People should be regarded as conscious individuals, as according to the art. 53 para. 1 they possess freedom of conscience. Therefore, they possess "conscience", so they consciously recognise and differentiate moral values (Judgement of the Constitutional Tribunal $-\mathrm{K} 12 / 14^{3}$ ), e.g. what is right/wrong, or what is true/ false. Hanna Suchocka regards these four fundamental constitutional values as universal because they bring together people of different worldviews - believers and nonbelievers (Suchocka, 2018, p. 55). Moreover, the Constitutional Tribunal declared in one of its judgements that truth, beauty and justice are values acknowledged by the whole society (Judgement of the Constitutional Tribunal - K 28/15). In other judgement Tribunal described good as a value precious for believers and non-believers (Judgement of the Constitutional Tribunal - K 52/13). It also seems that according to the Tribunal these values have a timeless character, as they should create bonds between generations (Judgement of the Constitutional Tribunal - Kp 2/15). So, it seems that assumption about common general understanding of them in the Polish society is justified.

The terms: truth, justice, good and beauty are generally the subject of analysis in many branches of science, especially philosophy and ethics. These researches and their results have many aspects. For the purpose of this article and because of the character of legal science as well as the constitutional characteristics of these values as "universal" there is a need to establish a clear meaning of these terms. It requires to use the language-logical method of the interpretation. The language-logical interpretation is based on the assumption that the terms used in the legal act, if not explained, should be understood according to their everyday meaning. Therefore the term "truth" means the logical characteristics of the statement which is vested to it only when in the reality there is a situation according to the statement matter. The term "justice" means a right and fair action or to award a person appropriately according to her/his influence on the work or to her/his achievements. The "good" means something that is beneficial, worthful or in accordance with ethics. The term "beauty"

3 The Polish Constitutional Tribunal judgements are available at: www.tribunal. gov.pl 
means a group of characteristics concerning the particular issue that make it likeable, it also means a high moral value.

The preamble also declares the "equality [of all citizens] in rights and obligations towards the common good - Poland" (Piechowiak, 2016, p. 138). Polish Constitution, like other constitutions, specifies some freedoms and rights as citizens' freedoms and rights and others as human freedoms and rights that belong to all people living in Poland. Therefore, it seems that the Polish citizens have more constitutional rights and freedoms than the foreigners and some freedoms and rights are accessible only for them (see: art. 11, art. 36, art. 60-62, art. 67, art. 99 and art. 127). However, as the Constitutional Tribunal stated in one of its verdicts, that if the Constitution describes "Polish citizen(s)" as the subject of the particular freedom or right it does not mean that it has to be restricted only to Polish citizens. The approach based on such "exclusivity" of the citizens' rights is not clearly justified by constitutional rules and not every extension of the citizens' freedom or right to other persons leads to the infringement of constitutional guarantees for such right (Judgement of the Constitutional Tribunal - K 18/04).

The phrase from the preamble on the equality of the citizens corresponds with art. 32-33 that concerns everyone (Piechowiak, 2016, p. 138). The first rule introduces the equality before the law and equal treatment by the public authorities. The second paragraph of this rule prohibits discrimination for any reason. The next article declares equal rights of men and women. These rules introduce the principle of the equality of citizens, as well as foreigners, stateless persons or organised units (Zajadło, 2012, p. 431). There is no reason that would justify public authorities to treat people differently in similar legal situation. Moreover, the public authorities should create the conditions for the actual equality of citizens, for example by progressive system of taxes (Litwin, 2016, pp. 206-211).

The most important aspect of the human nature is the human dignity. It is the right of every person (and only concerns the humans) to the self-fulfilment and to be treated as the subject of the actions. It concerns all spheres of human life (Garlicki, 2016, pp. 33$34,43,48-54)$. It should also be regarded as the right of every person of being the subject of respect of others (Granat, 2014, p. 16). The individual should be treated as free, autonomous and able to 
self-develop (Granat, 2014, pp. 16-17). According to art. 30 of the Constitution, the human dignity is "inherent, inalienable and inviolable". The term "inherent" means that human dignity starts from the moment of birth (Garlicki, 2016, p. 44). It is "inalienable", so it concerns, the entire human life (Garlicki, 2016, p. 44-45). It also means that an individual cannot effectively resign from the dignity even if that would be the act of the free will (Garlicki, 2016, p. 45). Also, there are no circumstances, conditions or actions committed by an individual that would allow to deprive him/her of dignity. (Garlicki, 2016, p. 45). The human dignity is also "inviolable", it remains with human being all the time, it cannot be "suspended" even in some special circumstances or conditions (Garlicki, 2016, p. 43). The art. 31 para. 3 can not be exercised towards human dignity, it is the only right from the constitutional catalogue of rights and freedoms that cannot be limited according to this rule of the Constitution (Judgement of the Constitutional Tribunal - K 2/98). The human dignity cannot be limited even when extraordinary measure is introduced (martial law, a state of emergency or a state of natural disaster) or even for potential protection of life of others (Judgement of the Constitutional Tribunal - K 44/07). Every violation of dignity should be automatically regarded as illegal (Granat, 2014, p. 17). It is also the "source of human and citizens' rights and freedoms". Hence, protection of the human dignity is the core of human rights in Poland and other detailed rights and freedoms expressed in the rules of law were introduced to protect the human dignity. Therefore, because of the source of human rights and inviolable character, in case of a conflict of human dignity with other constitutional value, human dignity should always be regarded as more important (Polak, Trzciński, 2018, p. 258). So, the protection of human dignity of individual justifies the limitation of rights and freedoms of others, for example freedom of speech (Judgement of the Constitutional Tribunal - P 10/06). Moreover, this also means that protection of the human dignity, as well as it specific aspects: freedom and equality of people should be included in the principles of state policies (Garlicki, 2016, pp. 39-40). Such interpretation is confirmed by the second phrase of art. 30 which states that "the respect and protection thereof shall be the obligation for public authorities". According to the preamble it includes "paying respect to the inherent dignity of the person" and respect for this principle is 
"the unshakeable foundation of the Republic of Poland". Therefore, there is a clear obligation for public authorities to protect the human dignity of the individual, although "paying respect to the inherent dignity of the person" is also an obligation concerning other subjects, such as private companies (Garlicki, 2016, pp. 45-48). This obligation could be regarded for example as an obligation for state authorities to ensure minimal standard of living for every person (Granat, 2014, pp. 18-19; Judgement of the Constitutional Tribunal - K 11/00). From this state obligation could be derived the requirement of minimal dignified salary which allows to meet certain justified living needs of an individual (minimum standard of a dignified life) (Judgement of the Constitutional Tribunal - K 31/03).

The last basic characteristics of the human nature that could be found in the Constitution is the freedom. This term should be regarded as the autonomy of an individual concerning her/his decisions in all aspects of her/his life. This autonomy concerns the possibility of taking up the particular action or refrain from it. It is also a general obligation to restrain from the interference in this sphere of autonomy of the individual (Judgement of the Constitutional Tribunal - K 1/14). It also means also that "no one shall be compelled to do that which is not required by law" (art. 31 para. 2). Therefore, art. 31 establishes the presumption that an individual possesses such autonomy which could be limited only by the rule of law (Garlicki, Wojtyczek, 2016, p. 58-59). The freedom of the individual is also a very important element of the constitutional axiology. According to the preamble, the Constitution was based on the respect of the freedom of the individual. The Constitution should be applied by "paying respect to the individual right to freedom" which is "unshakeable foundation of the Republic of Poland". Such "respect to the individual freedom" is an obligation for the public authorities but also it has a horizontal effect (Garlicki, Wojtyczek, 2016, pp. 65-68). The individual freedom has many aspects that were detailed in the Constitution (see: art. 20, art. 47, art. 52-54, art. 57-58, art. 65) (Bosek, 2016, p. 764). However, all constitutional rules concerning different aspects of human freedom are not covering all of the scope of the constitutional human freedom (Judgement of the Constitutional Tribunal - Sk 35/12). Because of its importance "freedom of the person shall receive legal protection" (art. 31 para. 1) and this is also an obligation for the public authorities 
(Garlicki, Wojtyczek, 2016, 65-66). According to art. 31 para. 2, the basic limitation of individual freedom are freedoms and rights of others, however, para. 3 of this rule allows to introduce other limitations - "only when they are necessary in a democratic state". This requirement brings the question if the conception of the "necessary in the democratic state" allows to limit the particular freedom or right. As previously mentioned, the art. 30, clearly regarding the human dignity as "inviolable", does not allow to introduce the limitations mentioned in art. 31 para. 3 (Garlicki, Wojtyczek, 2016, p. 74). The "democratic state" is a state with legal-political system which ensures conducting free, fair and universal elections in a regular and moderate time periods (Judgement of the Constitutional Tribunal - K 7/09) that allow for cyclic alternation of power. Moreover, it is a state where introduction of the law is based on broad social dialogue. It is also a state that complies with high standards of the protection of human rights and freedoms (Judgement of the Constitutional Tribunal U 10/07, Litwin, 2019, pp. 11-12). Therefore, the considered limitation of the particular freedom should be accompanied by a question whether it is in conformity with the conception of human rights in the democratic state. For example, art. 40 prohibits the tortures or cruel treatment or punishment. Although this rule does not refer to art. 31 para. 3, the limitation of this prohibition would be against the conception of the democratic state (Garlicki, Wojtyczek, 2016, pp. 71-72). The limitation of the freedom could be introduced by the bill and a legal act that has similar or higher power in the Polish legal system, e.g. Constitution, international agreement ratified according to art. 89 and secondary law of the EU (Garlicki, Wojtyczek 2019, pp. 79-80). As the principle, the limitation of the freedom could be introduced only for the protection of state security, public order, natural environment, health, public morals or the freedoms and rights of other persons (art. 31 para. 3). However, some of the rules of the Constitution include different premises of the limitation of the particular freedom. Such rules should be treated as lex specialis in contrast to art. 31 para. 3 which should be treated as lex generalis, however other requirements specified in art. 31, especially in para. 3, are still binding (Garlicki, Wojtyczek, 2016, pp. 75-77). Even if the particular limitation of freedom meets all these requirements, it still should not violate the essence of limited freedoms and rights (art. 31 para. 3). 
In general, the "essence of limited freedoms and rights" should be regarded as violated when the legal regulations, which formally do not abrogate the particular freedom or right, would practically make impossible to exercise it (Banaszak, 2012, p. 223). This rule inspired the Constitutional Tribunal to prepare verification of whether the particular regulation meets the requirements of proportionality, based on four questions:

1. Does the evaluated regulation is positive and necessary to construct the legal order in the particular area of the social relations?

2. Does the planned aim of the regulation is possible to reach without violation of the basic legal standards constructing the essence of the freedom or right which it concerns?

3. Does the statutory regulation is necessary to protect constitutional interest or values with which it is linked?

4. Does the effect of the introduced regulation remain in the appropriate proportion to the duties of the citizens? (Judgement of the Constitutional Tribunal - K 23/98)

\section{THE CONCEPTION OF POWER IN THE CONSTITUTION OF POLAND}

Generally, the term "power" seems to be regarded by law experts in two aspects: subjective and objective. In regard to the first aspect, "power" is a subject playing supreme role in the particular social relation and able to enforce the particular way of behaviour of others, for example: monarch, state organ, nation. In regard to the second aspect "power" is a social phenomenon resulting in the conscious interactions of the people as members of the society. Therefore, the "power" is a subordination of one individual towards another one, specific relation of dependence that allows the subject of power (governing individual) to enforce the desired behaviour of the object of power (governed individual) (Banaszak, 2012, p. 58).

The Constitution in its text distinguishes three sorts of power: supreme power, public power and state power. In general, the supreme power is regarded as having such characteristics as: originality, permanence, self-determination, omni-comprehensiveness and 
illimitability. The "originality" means that supreme power is not legitimised by any other sorts of power, the source of the legitimisation should be other than power. The "permanence" means that the supreme power is not influenced by the passage of time, even if the system of governance, governments, or institutions of the legal-political system change. The "self-determination" means the independence, albeit not absolute, of the supreme power from the external power. The essence of it is independence in the legal sense concerns decisions on the relations with other states. The "omni-comprehensiveness" means that the supreme power is independent in the internal relations from any factors and free in shaping the internal relations such as political system or socioeconomic system. The supreme power concerns the whole territory of state and every individual on its territory, although if there is a strong bond between the state and an individual, like citizenship, the power can be exercised even outside of the state territory. The "illimitability" of the supreme power brings the most controversies. In Poland, a "democratic state ruled by law" (art. 2 of the Constitution) limitations include law, constitution or rules of law that guarantee the human rights and freedoms (Banaszak, 2012, pp. 58-60; Winczorek, 2008, p. 24).

The art. 4 para. 1 declares that "supreme power in the Republic of Poland shall be vested in the Nation". The term "Nation" should be understood as "political nation" not ethnic (Judgement of the Constitutional Tribunal - K 15/04), as explained in the preamble "all citizens of the Republic of Poland" but also Poles living abroad (art. 6 para. 2 of the Constitution) (Szmyt, 2008, p. 304). According to art. 4 para. 2, the general form of exercising the power is to make it through "the representatives of the Nation", which term according to the Tribunal should be understood broadly (Judgement of the Constitutional Tribunal - K17/98), but it does not exclude to exercise by nation its power concurrently in the form of direct democracy. However, even when such representatives exercise the "supreme power", it remains with the Nation (Szmyt, 2008, p. 303), being only delegated to the organs of "public power", divided according to art. 10, and is subordinate to the "supreme power" (Florczak-Wątor, 2016, p. 271; Kuca, 2014, pp. 29-30; Litwin, 2018, pp. 18-20).

The public power and state power are exercised, respectively, by organs of public power and organs of state power. The state power is 
exercised by the state and state organs, the public power is exercised by the state, its organs and by the institutions of the self-government (Winczorek, 2011, pp. 31-32).

According to art. 10 of the Constitution which expressly introduces the principle of division of power (Kuca, 2014, p. 89), the state power exercised by the public authorities is divided into legislative, executive and judicial branches (functional division). All these branches are vested, respectively, by the appropriate and different state organs: Sejm and Senate (organs of legislative power), President and Council of Ministers (organs of executive power), courts and tribunals (organs of judicial power) (the structural aspect of organisational division). Therefore, there are constitutional state organs that are not included in the principle of division of power scheme, e.g. National Council of Radio Broadcasting and Television (Judgement of the Constitutional Tribunal - K 4/06). However, there are also constitutional organs of public power that are not mentioned in the art. 10 but can be assigned to the particular branch of power. The Constitutional Tribunal for example regards self-government as assigned to executive branch (Judgement of the Constitutional Tribunal - P 16/04). This aspects of the principle of division of power is also linked with the obligation to establish appropriate competences for each of the mentioned organs, according to the assignment of the particular organ to the appropriate branch of power. Also, the organs of state power that are assigned to the particular branch of power should possess at least minimal scope of competences that would enable them to realise it. The principle of division of power has also the personal aspect, which should be understood as general prohibition of holding at the same time the offices in the organs belonging to different branches of power. This aspect of the principle was dealt with in art. 103 para. 2, art. 108, art. 132 and art. 178 para. 3. The combined interpretation of these rules limits the possibility of holding the office of President of Republic of Poland together with parliamentary mandate or position of a judge and also excludes holding the office of judge and parliamentary mandate. The only exception from that principle in its personal aspect is the clear allowance expressed in art. 103 para. 1 in finé to hold at the same time parliamentary mandate and membership in the Council of Ministers. In the European legal systems, the principle of division of power linked with the parliamentary system of governance allows 
for relations between the legislative power and the executive power based on various forms of cooperation and interactions. It is also admissible to establish areas where the competences of organs of these two branches of power "crisscross" or "overlap". By contrast, relations between the judiciary and the other branches of power must be based on the principles of separation and prohibition of interference with other branches in the area of independence of courts and justices. The mutual relations between all branches of power are also based on the principles of balance which should be ensured by the system of checks that guarantees each branch of power to restrain the other two branches (Kuca, 2014, pp. 89-114, 120-126; Małajny, 2017, pp. 97-123, Judgement of the Constitutional Tribunal - K 39/16). However, the principle of division of power does not require the balance between the organs of particular branch as for example Sejm have stronger constitutional position than Senate as both are the organs of legislative power (Judgement of the Constitutional Tribunal - K 24/04).

Such regulation should limit the possibility of concentration of power by one of the public power organs, that could possibly replace the Nation as the subject in which supreme power should be vested, and therefore it also safeguards individual's human rights and freedoms from abuse of power (Pach, Tuleja, 2016, p. 342; Kuca, 2014, p. 13; Judgement of the Constitutional Tribunal - K 8/99). Still it should be remembered that according to the preamble the organs of state power are not separate institutions but they should cooperate with each other because it is one of the "basics of the Constitution of Republic of Poland" (Kuca, 2014, pp. 114-120).

The power in Poland is also decentralised (art. 15 para. 1). The decentralisation concerns all "public power" which means all sorts of it and all public organs. There are three basic aspects of the decentralisation of power. The first one concerns the division of competences between "central" organs and other organs associated with the territorial system of Poland. Even when a particular competence was devolved from "central" to "non-central" organ, it could be returned back to the "central" organ (Judgement of the Constitutional Tribunal - K 34/01). Such division should be established by the act of law. The competences of "non-central" organs should be significant. Such understanding of the decentralisation is also supported by the principle of subsidiarity meaning that that the responsibility 
for public business should be vested in the organs of public authority that are most accessible for the citizens, i.e. local organs of public power. Therefore, the structure of the organs of public power should include "central" and "local" organs of public power with the necessary scope of competences. The second aspect of the decentralisation concerns the appropriate scope of independence and autonomy of "non-central" organs in exercising their particular competences. The last aspect deals with ensuring appropriate financial measures and independence in financial policy of "non-central" organs (Skoczylas, Piątek 2016, pp. 403-406).

The principle of decentralisation of power is closely related to the principles of democracy and sovereignty of the nation. The decentralised structure of the public power allows to better satisfy citizens' needs and it also enables citizens to easier influence the functioning of the organs of public power (Sarnecki, 2016, p. 467). This principle seems to be even more closely related to the principle of division of power, as it is sometimes called the vertical aspect of the latter principle (Winczorek, 2008, p. 37-38; Florczak-Wątor, 2019, p. 55). The decentralisation could be regarded as concerning all three branches of power: legislative, judicial and executive. The right of Polish citizens to participate in referendum and possibility of adopting the law by self-government might be regarded as examples of decentralisation of the legislative branch. Such examples are also two instance structure of judiciary system as well as exercising the tasks of executive power by self-government (Kieres, 2020, pp. 68-70). Both principles should also ensure mutual restraint of the organs of public power and their mutual completion (Wójtowicz, 2012, pp. 33, 375-376).

\section{THE PURPOSES OF POWER AND THEIR RELATIONS WITH THE CONCEPTION OF HUMAN NATURE}

The general purposes that should justify the existence of power are described in art. 5 of the Constitution. According to this rule:

The Republic of Poland shall safeguard the independence and integrity of its territory and ensure the freedoms and rights of persons and citizens, the security of the citizens, safeguard the national heritage 
and shall ensure the protection of the natural environment pursuant to the principles of sustainable development.

This rule applies to all organs of public power, which are responsible for the realisation of those aims (Banaszak, 2012, p. 69; FlorczakWątor 2016, pp. 286, 288; Sarnecki, 2016, p. 231), including organs of executive, legislative, and judiciary power as well as organs of selfgovernment, which should all of its competences for their realisation (Judgement of the Constitutional Tribunal - Kp 2/09).

Are such purposes justified by the constitutional conception of the human nature? The first purpose, "to safeguard the independence of Poland and integrity of its territory", justified by the history of Poland (Florczak-Wątor, 2016, p. 285), seems to be the most important and also essential for realisation of the other purposes described in art. 5 (Skrzydło, 2013, p. 20). The "independence of Poland" should be understood as autonomy of Poland and independence in international relations and from external subjects (Florczak-Wątor, 2016, p. 285). The "safeguarding" means using many measures for the protection of independence, such as different sorts of policies (Banaszak, 2012, p. 69). However, this aim cannot be understood as supporting the policy of isolationism and against Poland's membership in the EU (Sarnecki, 2016, p. 232). The question is if such purpose could be an obstacle for further integration with EU which could become a guarantee of the safety of Poland. Moreover, EU can also be regarded as a guarantee of high standards of human rights protection. The "integrity of the territory" is one of the elements concerning population and political power constructing the state. Therefore, the loss of supremacy on a part of its territory should be regarded as the danger for the existence of state. The Polish state exercises the supremacy on its whole territory, however, it can transfer some scope of the supremacy on a part of territory to other states or international organisations by the way of bill or international agreement (art. 90 and art. 117) (Florczak-Wątor, 2016, pp. 286-287). Therefore, in the light of art. 5 and other rules of the Constitution. public authorities cannot allow to loose any part of the Polish territory in result of any sort of action, not even by the way of profitable selling. It also seems that the Constitution does not allow to increase the territory of Poland, especially at the expense of the other countries. Such strict 
interpretation of the term "integrity of the territory of Republic of Poland" from art. 5 seems to be supported by art. 9 and fragment of the preamble regarding "cooperation with all countries for the good of the Human Family" as the constitutional value.

The purpose "to ensure the freedoms and rights of persons and citizens", corresponds with the obligation of the of public authorities to protect human dignity (art. 30) which is the source of every human freedom and right and with international agreements on the protection of human rights (art. 9 of the Constitution) (Tuleja, 2019, p. 41). The obligation to ensure human freedoms and rights should be understood as obligation of organs of public power to act or to restrain from acting in order to protect the mentioned freedoms and rights (Florczak-Wątor, 2016, p. 287). However, it should be remembered that very often it is the action(s) of public authorities that endanger human rights and freedoms (Complak, 2014, p. 18).

The next purpose is to protect "security of the citizens". The term "security" should be understood broadly as concerning the internal and external security and their various aspects (Banaszak, 2012, p. 73; Florczak-Wątor, 2016, p. 288). An assumption could be made that under normal circumstances the main danger for the safety of citizens are actions of other citizens (Sarnecki, 2016, p. 234), such as crime or road traffic accidents. Crime and hazardous driving are not in accordance with the constitutional description of the human nature saying that Polish citizens accept truth, justice, good and beauty as universal values.

Other purpose expressed in art. 5 of the Constitution, is to "safeguard the national heritage". This aim should be understood as the obligation to protect all material and non-material factors which existed during the history of development of the Polish state and society, confirming its identity and equal position among other nations. The national heritage developed by one generation should be passed to the next one for further development. It could, however, also include some negative phenomena that should be passed to the next generations for educational reasons (Florczak-Wątor 2016, pp. 288-289; Sarnecki, 2016, pp. 234-235). This purpose could be regarded as an element of integration of the Polish society.

The last purpose "protection of the natural environment" could be regarded as a general order (Banaszak, 2012, p. 74). The unique 
natural environment of Poland should be treated as equally important to culture or the Polish language, as the elements constructing the Polish state and its identity (Sarnecki, 2016, p. 235). This purpose should also be understood as the obligation for the public authorities to conduct strategic policy concerning the environmental issues that supports not only protection of the natural environment but also its development (Sarnecki, 2016, p. 235). However, the protection should be made "pursuant to the principles of sustainable development". This means that the policy of the state supporting broadly regarded civilizational development should consider its influence on the natural environment. This influence should have the least harmful effect and social profits should exceed the potential environmental damages. The principles of sustainable development include not only the protection of nature or shaping the spatial order, but also due care for social and civilisational development, related to the need to build appropriate infrastructure necessary for the life of people and individual communities and taking into account civilisation needs. Therefore, the principle of sustainable development requires to balance different constitutional values (Judgement of the Constitutional Tribunal - K 23/05). In this context, the protection of the natural environment should allow the present and future generations to equally benefit from it (Banaszak, 2012, pp. 74-75; Florczak-Wątor, 2016, pp. 289-290). Such purpose of the public power does not seem to be justified by the constitutional conception of the human nature. The citizens who recognise the "beauty" and "good" as ("universal") values shall effectively protect environment and not undertake actions worsening its state.

\section{FINAL REMARKS}

The analysis of relations between the vision of the human nature and the construction and general purposes of the power presented in the Constitution leads to the conclusion that the construction and general purposes of power are only partially justified by the constitutional vision of human nature. According to the preamble and rules of the Constitution people seem to be regarded as conscious individuals who by their conscience recognise as values: truth, justice, good and 
beauty. The power in Poland is limited because it is divided and decentralised. Taking into account quite positive constitutional vision of the human nature, such position of power seems to be surprising. If we regard people in such way as it is presented in the Constitution, all the limitations of power seem to be unnecessary obstacles. The construction of power, however, seems to be based on other presumption concerning the human nature. The power should be limited because of mixed nature of people who are exercising the power and because of the conviction that "power tends to corrupt". The purposes justifying the existence of the power and state expressed in art. 5 seem to be rational, however, they are also not correspondent with the conception of the human nature presented in the preamble but rather correspondent with the conception of human nature presented above.

It is because the conception of the described universal values recognised in Polish society is artificial and unnecessary. First of all, no sociological or anthropological research confirm that such values are important for the Polish citizens. Even If eventual research would confirm that the mentioned values are important in the Polish society, this would only concern the declarations not the actions of the Polish citizens. Moreover, even If we would make an assumption that Polish citizens believe in the mentioned values and try to live according to them we should take into account that people do not always behave in such manner, often our actions depend on the particular circumstances. The preamble proclaim those values as being "universal" it means that they are also "universally" understand by Polish citizens. The last assumption also seems to be false because societies are very often strongly divided. The context of the formulation of the values also makes the impression that in Poland there is special need to justify the equal status of believers and non-believers, although equality of citizens is natural characteristic of the democratic state which Poland is (art. 2 of the Constitution).

In my opinion the constitution should not make any declarations concerning human nature, such values as: truth, justice, good and beauty should be rather regarded as the part of the constitutional axiology but not the generally accepted values among Polish citizens. The appropriate regulation could be a result of the amending art. 8 of the Constitution which characterises the Constitution as the supreme law in Poland and confirm as the principle the direct application of its 
rules. This rule could be developed that the Constitution safeguards such values as: truth, justice, good and beauty. All this values had roots in the philosophy of ancient Greeks (Piechowiak, 2016, p. 135) however this enumeration does not include one value, also very important in the philosophy of ancient Greeks, which is wisdom.

It seems that general characteristics of the construction of power and the presumption concerning the human nature on which it is based is right. The supreme power shall be vested in nation, the power shall be divided and decentralised accordingly to the principle of subsidiarity. However, the problem with power in Poland is that detailed provisions are not in conformity with the described general characteristics of power. The detailed analysis of this problem is beyond the scope of this article, however I would like present some general proposals aimed at improving that conformity:

- introduction of referendum conducted on demand of citizens;

- strengthening the separation and independence of judicial power;

- reform of electoral system of President and Senate;

- strengthening the position of self-government, especially concerning the constitutional rules on its competences and financial autonomy.

\section{BIBLIOGRAPHY}

Banaszak, B. (2012). Konstytucja Rzeczypospolitej Polskiej. Komentarz. Warszawa: Wydawnictwo C.H. Beck.

Bosek, L., (2016b). Uwagi do art. 31 ust. 1-2. In M. Safjan \& L. Bosek (eds.), Konstytucja RP. Tom I. Komentarz. Art. 1-86 (pp. 751-770). Warszawa: Wydawnictwo C.H. Beck.

Complak, K. (2014). Uwagi do art. 5. In M. Haczkowska (ed.) Komentarz. Konstytucja Rzeczypospolitej Polskiej (pp. 18-19). Warszawa: LexisNexis.

Florczak-Wątor, M. (2016) Uwagi do art. 4-5. In M. Safjan \& L. Bosek (eds.), Konstytucja RP. Tom I. Komentarz. Art. 1-86 (pp. 256-278). Warszawa: Wydawnictwo C.H. Beck.

Florczak-Wątor, M. (2019). Uwagi do art. 10. In: P. Tuleja (ed.), Konstytucja Rzeczypospolitej Polskiej. Komentarz (pp. 55-58). Warszawa: Wolters Kluwer. 
Garlicki, L., Derlatka M. (2016). Wstęp. In L. Garlicki \& M. Zubik (eds.), Konstytucja Rzeczypospolitej Polskiej. Komentarz (pp.17-40). Vol. 1. Warszawa: Wydawnictwo Sejmowe.

Garlicki, L. (2016). Uwagi do art. 30. In L. Garlicki \& M. Zubik (eds.), Konstytucja Rzeczypospolitej Polskiej. Komentarz (pp. 27-54). Vol. 2. Warszawa: Wydawnictwo Sejmowe.

Garlicki, L., Wojtyczek K. (2016). Uwagi do art. 31. In: L. Garlicki \& M. Zubik (eds.), Konstytucja Rzeczypospolitej Polskiej. Komentarz (pp.55100). Vol. 2. Warszawa: Wydawnictwo Sejmowe.

Granat, M. (2014). Godność człowieka z art. 30 Konstytucji RP jako wartość i jako norma prawna. Państwo i Prawo, LXX (8), 3-22.

Judgement of the Constitutional Tribunal, reference symbol: K 17/98, 26th May 1998.

Judgement of the Constitutional Tribunal, reference symbol: K 23/98, 25th February 1999.

Judgement of the Constitutional Tribunal, reference symbol: K 2/98, 23rd March 1999.

Judgement of the Constitutional Tribunal, reference symbol: K 8/99, 14th April 1999.

Judgement of the Constitutional Tribunal, reference symbol: K 11/00, 4th April 2001.

Judgement of the Constitutional Tribunal, reference symbol: K 34/01, 25th November 2002.

Judgement of the Constitutional Tribunal, reference symbol: K 15/04, 31st May 2004.

Judgement of the Constitutional Tribunal, reference symbol: K 31/03, 10th January 2005.

Judgement of the Constitutional Tribunal, reference symbol: K 24/04, 12th January 2005.

Judgement of the Constitutional Tribunal, reference symbol: K 18/04, 11th May 2005.

Judgement of the Constitutional Tribunal, reference symbol: P 16/04, 29th November 2005.

Judgement of the Constitutional Tribunal, reference symbol: K 23/05, 6th June 2006.

Judgement of the Constitutional Tribunal, reference symbol: K 4/06, 23rd March 2006.

Judgement of the Constitutional Tribunal, reference symbol: P 10/06, 30th October 2006.

Judgement of the Constitutional Tribunal, reference symbol: K 44/07, 30th September 2008. 
Judgement of the Constitutional Tribunal, reference symbol: Kp 2/09, 13th May 2009.

Judgement of the Constitutional Tribunal, reference symbol: K 7/09, 21st July 2009.

Judgement of the Constitutional Tribunal, reference symbol: U 10/07, 2nd December 2009.

Judgement of the Constitutional Tribunal, reference symbol: Sk 35/12, 17th July 2014.

Judgement of the Constitutional Tribunal, reference symbol: K 52/13, 10th December 2014.

Judgement of the Constitutional Tribunal, reference symbol: Kp 2/15, 25th May 2015.

Judgement of the Constitutional Tribunal, reference symbol: K 12/14, 7th October 2015.

Judgement of the Constitutional Tribunal, reference symbol: K 1/14, 4th November 2015.

Judgement of the Constitutional Tribunal, reference symbol: K 28/15, 12th July 2016.

Judgement of the Constitutional Tribunal, reference symbol: K 39/16, 11th August 2016.

Kieres, L. (2020). Decentralizacja w ujęciu Konstytucji RP: Orzecznictwo Trybunału Konstytucyjnego. Samorzad Terytorialny, (3), 65-81.

Kuca, G. (2014). Zasada podziału władzy w Konstytucji RP z 1997 roku. Warszawa: Wydawnictwo Sejmowe.

Litwin, T. (2016). Konstytucyjność zmiany skali podatku PIT z 2006 roku. Horyzonty Polityki, 7 (20), 195-213. DOI: 10.17399/ HP.2016.072010

Litwin, T. (2018). Pojęcie "przedstawiciela Narodu” w świetle art. 4 ust. 2 Konstytucji RP z 1997 r. Horyzonty Polityki, 9(26), 11-31.

Litwin, T. (2019), Wstęp. In T. Litwin, K. Łabędź \& R. Zyzik, Aktualna debata wokót zasad ustrojowych w Polsce (pp. 7-16). Kraków: Wydawnictwo Naukowe Akademii Ignatianum w Krakowie.

Małajny, R.M. (1985). Doktryna podziału władzy „Ojców Konstytucji” USA. Katowice: Uniwersytet Śląski.

Małajny, R.M. (2017). Podział władzy w Konstytucji RP z 1997 roku. Analiza formalna. Przeglad Sejmowy, 6 (143), 97-123.

Pach, M., Tuleja P. (2016). Uwagi do art. 10. In: M. Safjan \& L. Bosek (eds.), Konstytucja RP. Tom I. Komentarz. Art. 1-86 (pp. 335-352). Warszawa: Wydawnictwo C.H. Beck.

Piechowiak, M. (2016). Preambuła. In M. Safjan \& L. Bosek (eds.), Konstytucja RP. Tom I. Komentarz. Art. 1-86 (pp. 118-158). Warszawa: Wydawnictwo C.H. Beck. 
Piechowiak, M. (2020). Preambuła Konstytucji Rzeczypospolitej Polskiej z 1997 r. Aksjologiczne podstawy prawa. Warszawa: Wydawnictwo C.H. Beck.

Polak, P., \& Trzciński, J. (2018). Konstytucyjna zasada godności człowieka w świetle orzecznictwa Trybunału Konstytucyjnego. Gdańskie Studia Prawnicze, (XL), 257-274.

Sarnecki, P. (2016a). Uwagi do art. 5 i art. 15. In L. Garlicki \& M. Zubik (eds.), Konstytucja Rzeczypospolitej Polskiej. Komentarz (pp. 230-236, 464-472). Vol. 1. Warszawa: Wydawnictwo Sejmowe.

Skoczylas, A., Piątek W. (2016). Uwagi do art. 15. In M. Safjan \& L. Bosek (eds.), Konstytucja RP. Tom I. Komentarz. Art. 1-86 (pp. 397-411). Warszawa: Wydawnictwo C.H. Beck.

Skrzydło, W. (2013), Konstytucja Rzeczypospolitej Polskiej. Komentarz. Warszawa: Wolters Kluwer Polska.

Suchocka, H. (2018). Aktualność wartości chronionych przez konstytucję z 1997 r. Gdańskie Studia Prawnicze, XL, 49-63.

Szmyt, A. (2009). Normatywny wyraz idei demokracji przedstawicielskiej i bezpośredniej w Konstytucji RP z 1997 roku. Gdańskie Studia Prawnicze, XX, 301-313.

Tuleja, P. (2019a). Uwagi do preambuły, art. 5. In P. Tuleja (ed.), Konstytucja Rzeczypospolitej Polskiej. Komentarz (pp. 21-24, 40-42). Warszawa: Wolters Kluwer.

Winczorek, P. (2008). Komentarz do Konstytucji Rzeczypospolitej Polskiej $z$ dnia 2 kwietnia 1997 roku. Warszawa: LIBER

Winczorek, P. (2011). Nauka o państwie. Warszawa: LIBER.

Wójtowicz, D. (2012). Decentralizacja władzy publicznej we Francji w drugiej połowie XX wieku. Toruń: Wydawnictwo Adam Marszałek.

Zajadło, J. (2012). Godność, wolność i równość w Konstytucji RP (szkic encyklopedyczny). Gdańskie Studia Prawnicze, XXVII, 423-435.

\section{Copyright and License}

This article is published under the terms of the Creative Commons Attribution - NoDerivs (CC BY- ND 4.0) License http://creativecommons.org/licenses/by-nd/4.0/ 